\title{
MR zobrazování
}

\section{u extrapyramidových onemocnění}

\author{
prof. MUDr. Josef Vymazal, D.Sc.', MUDr. Petra Havránková, Ph.D. ${ }^{2}$ \\ 'Radiodiagnostické oddělení, Nemocnice Na Homolce, Praha \\ ${ }^{2}$ Neurologická klinika 1. LF UK, Praha
}

Článek podává přehled o možnostech diagnostiky a základní diferenciální diagnostiky extrapyramidových onemocnění pomocí magnetické rezonance. Soustředuje se na rozlišení mezi Parkinsonovou nemocí, atypickými parkinsonskými syndromy, dále popisuje charakteristický MR obraz Huntingtonovy choroby a Wilsonovy nemoci. V rámci širší diferenciální diagnostiky je zmíněn i chronický subdurální hematom a normotenzní hydrocefalus.

Klíčová slova: magnetická rezonance (MR), počítačová tomografie (CT), Parkinsonova nemoc, mnohočetná systémová atrofie, hydrocefalus.

\section{MR imaging in extrapyramidal diseases}

The article provides an overview of diagnostic options and basic differential diagnostic approaches for extrapyramidal diseases using magnetic resonance imaging. It aims at distinguishing between Parkinson's disease and atypical parkinsonian syndromes as well as describes the characteristic presentation of Huntington's disease and Wilson's disease on magnetic resonance imaging. Moreover, chronic subdural haematoma and normal pressure hydrocephalus are discussed as part of a broader differential diagnosis.

Key words: magnetic resonance imaging (MR), computed tomography (CT), Parkinson's disease, multiple system atrophy, hydrocephalus.

\section{Úvod}

Diagnostika a diferenciální diagnostika extrapyramidových onemocnění byla a do značné míry stále zůstává doménou klinického neurologického vyšetření. Zavedení počítačové tomografie (CT) do klinické medicíny zlepšilo diagnostiku těžších cévních postižení mozku a dokázalo odlišit jiná onemocnění, která se mohou projevovat podobně, např́klad chronický subdurální hematom či normotenzní hydrocefalus. Nicméně podrobnější zobrazování extrapyramidových onemocnění umožnil v posledních desetiletích až rychlý rozvoj magnetické rezonance (MR). MR sice nezasáhla významněji do diagnostiky napřiklad Parkinsonovy choroby, avšak jak standardní MR zobrazení, tak i moderní kvantitativní techniky, významně přispěly k diferenciální diagnostice. $V$ poslední době se výzkum neurodegenerativních a extrapyramidových onemocnění zaměřuje i na hledání biomarkerů prodromálních či časných stadií onemocnění, která nabízí větší potenciál pro terapeutickou intervenci. Slibné biomarkery se hledají mj. pomocí sofistikovaných MR protokolů, například variety funkčního MR zobrazování tzv. resting state MR (Postuma, 2016).

$\checkmark$ dalším textu probereme jednotlivá onemocnění charakterizovaná extrapyramidovou symptomatologií se zaměřením na jejich MR obraz.

\section{Parkinsonova nemoc \\ Parkinsonova nemoc (PN) je chronické neurodegenerativní onemocnění, způsobené předčasnou ztrátou dopaminergních neuronů}

v substantia nigra. Základní klinická trias charakterizující PN zahrnuje hypokinezi, rigiditu a tremor. K této trias se pripojuje porucha posturálních funkcí jako dalši důležitý klinický symptom.

\section{MR charakteristika}

Diagnóza Parkinsonovy nemoci je především klinická. MR může v diagnostice napomoci, a to jak určitými specifičtějšími charakteristikami, tak především vyloučením jiné etiologie onemocnění.

Hlavní MR charakteristikou Parkinsonovy nemoci, ale i některých atypických parkinsonských syndromů (mnohotná systémová atrofie) je vizualizace degenerace pars compacta substantiae nigrae. NaT2 váženém obraze především u sekvencí klasického spinového echa (SE) můžeme pozorovat 


\section{\ HLAVNÍ TÉMA}

Obr. 1. Parkinsonova nemoc - degenerace pars compacta substantiae nigrae projevujici se oboustrannè splynutím signálu pars reticulata a nucleus ruber; SE sekvence v T2 váženi

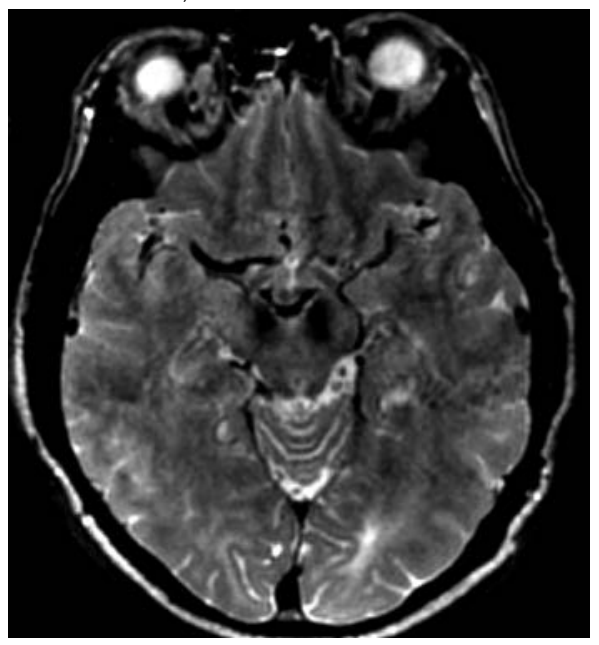

Obr. 2. Nucleus subthalamicus - zobrazení na prístroji 3 Tesla pred implantací neurostimulátoru

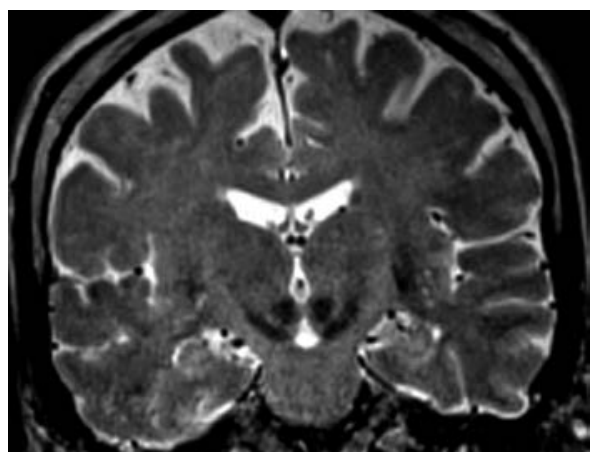

zúžení relativně hyperintenzního proužku pars compacta, který je lokalizován mezi pars reticulata substantiae nigrae a nucleus ruber, prípadně dochází k jeho úplnému splynutí s fyziologicky hypointenzní pars reticulata a nucleus ruber (obrázek 1) (Duguid, De La Paz et DeGroot). Tento príznak uvádíme pro úplnost, v klinické praxi ho běžně nevídáme mimo jiné i díky použivání sekvencí rychlého spinového echa (FSE či TSE), kdy není díky koncepci těchto sekvencí často spolehlivě zobrazen. Důležitým faktem pro diferenciální diagnostiku je skutečnost, že signál z bazálních ganglií je u Parkinsonovy nemoci na všech typech vážení MR obrazu v drtivé většině v normě. V současné době je vhodné zdůraznit i roli difuzně váženého zobrazení a zobrazení difuzního tenzoru s nálezem snižené integrity v oblasti substantia nigra.

Role neuroradiologa je, krom diferenciální diagnostiky Parkinsonovy nemoci, důležitá rovněž při intervenční léčbě tohoto onemocnění. Tato léčba je indikována v pokročilých stadiích choroby při nedostatečném účinku běžné farmakologické léčby. Nejčastěji využívanou metodou je v současnosti hluboká mozková stimulace.
Jedná se o trvalou elektrickou stimulaci bud' nucleus subthalamicus nebo globus pallidus. Úlohou neuroradiologa před implantací neurostimulátoru je přesné zobrazení nucleus subthalamicus (corpus Luyisii) (Růžička et al., 2004). Jedná se o diskrétní jádro, které akumuluje železo ve formě metaloproteinu ferritinu, a proto má na T2 a T2* vážených sekvencích nízký signál (jde o identickou etiologii nízkého signálu v nucleus ruber a v pars reticulata substantitae nigrae). Zobrazení subtilního nucleus subthalamicus není snadné a lépe se provádí na prístrojích s vyšším magnetickým polem, a to díky obecně vyššímu signálu a rovněžz důvodu, že MR efekt zobrazení ferritinu se zvyšuje s rostoucí silou vnějšího magnetického pole (obrázek 2). Dalším možným cílem stimulace je globus pallidus, jehož MR zobrazení je naopak snadné.

\section{Mnohotná systémová atrofie}

Mnohotná systémová atrofie (MSA) zahrnuje skupinu onemocnění, která se projevují parkinsonským syndromem, zpravidla minimálně reagujícím na léčbu L-Dopou. Přítomny bývají i další neurologické přiznaky (mozečkový syndrom, léze pyramidové dráhy a autonomní poruchy) (Vymazal, 2009).

V současné době dělíme MSA na dvě formy - s převažujícím parkinsonským syndromem (MSA - P) a s převažujícím mozečkovým syndromem (MSA - C).

\section{MSA - P}

Jde o onemocnění nejasné etiologie charakterizované rychle progredujícím parkinsonským syndromem se špatnou nebo nulovou reakcí na dopaminergní léčbu a časnými autonomními poruchami (ortostatická hypotenze, poruchy sfinkterů). Přidružit se může i postižení pyramidové dráhy či mozečkový syndrom.

\section{MR charakteristika}

Na rozdíl od PD pozorujeme v dorzální části putamen hypointenzní zónu signálu na T1 a T2 vážených obrazech. Nejedná se o prodloužení T1 relaxačního času, ale T1 hypointenzita je vysvětlována jako T2 efekt patrný na T1 váženém obraze, pravděpodobně způsobený akumulací ve vodě nerozpustného hemosiderinu (obrázek 3). Na rozdíl od tohoto jevu pozorovatelného prostým okem bylo relaxometricky detekováno zkrácení T2 i T1 relaxačního času v pallidu, v tomto prípadě
Obr. 3. MSA typ P. a) SE sekvence v T1 váženíprokazuje diskrétní, ale evidentni snižení intenzity signálu v dorzální části putamen více vlevo, odpovídajícíakumulaci hemosiderinu b) sekvence gradientního echa $v T 2^{*}$ váženís výrazně hypointenzním signálem díky akumulaci železitých metaloproteinů, predevším hemosiderinu a ferritinu v putamen a rovněžv vallidu oboustranně. Signál z pallida nelze považovat jednoznačněza patologický

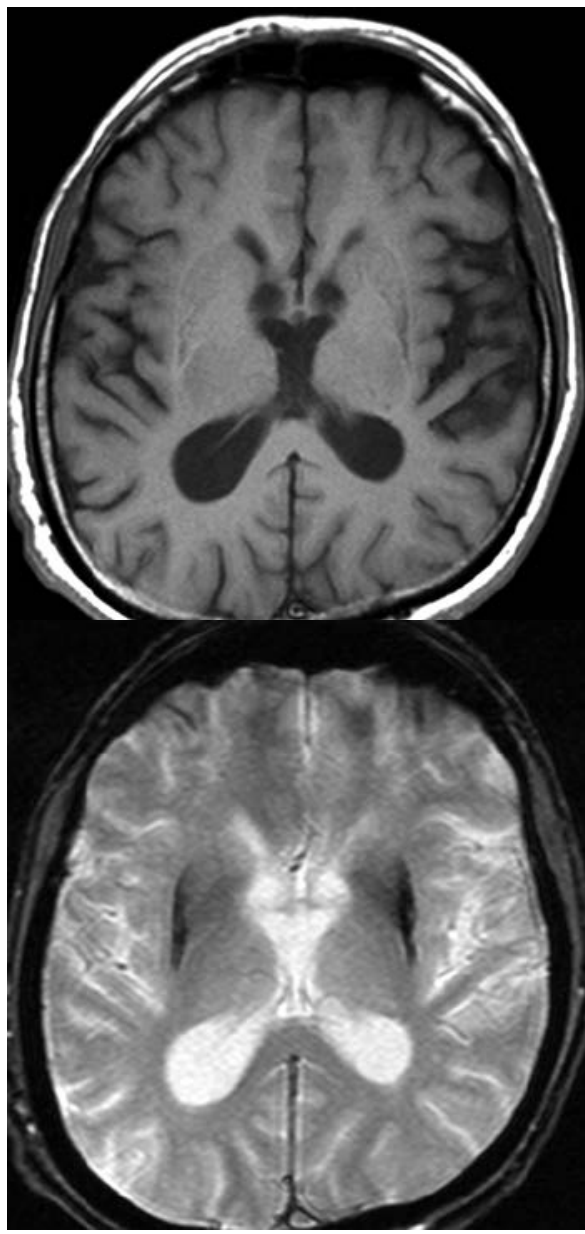

Obr. 4. Protonová MR spektroskopie prokazuje snižený signal N-acetyl-aspartátu ve srovnánís cholinem u pacienta s MSA typ $P$

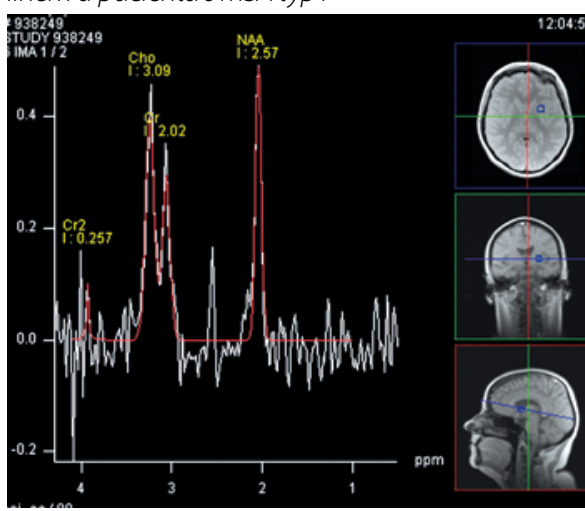

se jedná s největší pravděpodobností o akumulaci ferritinu, který je ve vodě rozpustný a umožní proto dipól-dipólovou interakci potřebnou ke zkráceníT1 relaxačního času (Vymazal, Urgošík et Bulte, 2000). Tento efekt však nebývá pozorovatelný prostým okem, proto základní MR charakteris- 
Obr. 5. Hot-cross-bun príznak; protonově-denzitní vážení, sekvence FSE. Pacient s MSA typ P

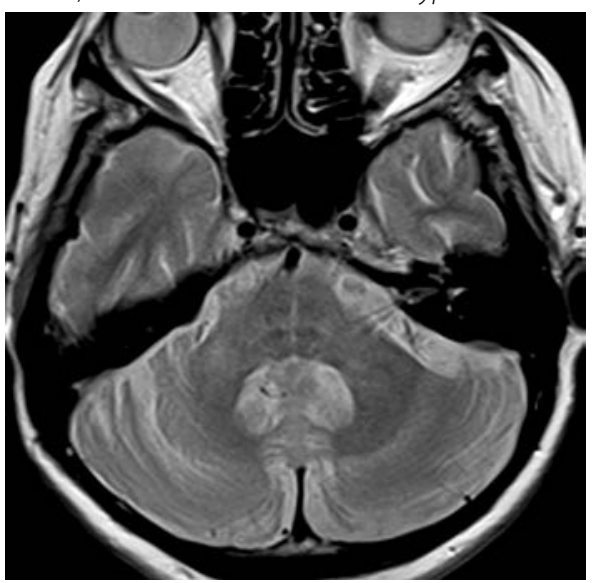

Obr. 6. Disproporčni atrofie kmene i mozečku se spoluprítomným hot-cross-bun príznakem; T2vážený obraz, FSE sekvence; pacients s MSA typ C

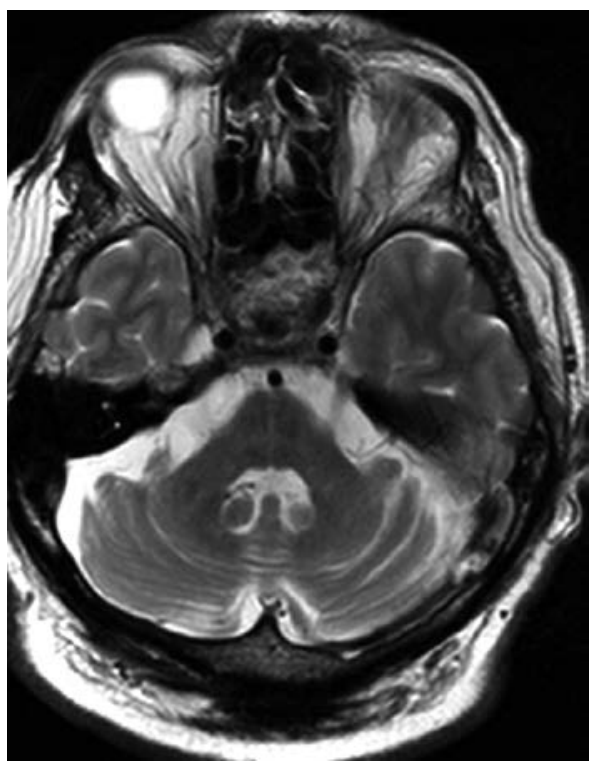

Obr. 7. Huntingtonova chorea - sekvence gradientního echa v T1 vážení; dominuje atrofie nucleus caudatus s rozširirením frontálních rohů postrannich komor, prítomna rovněž povšechná mozková atrofie

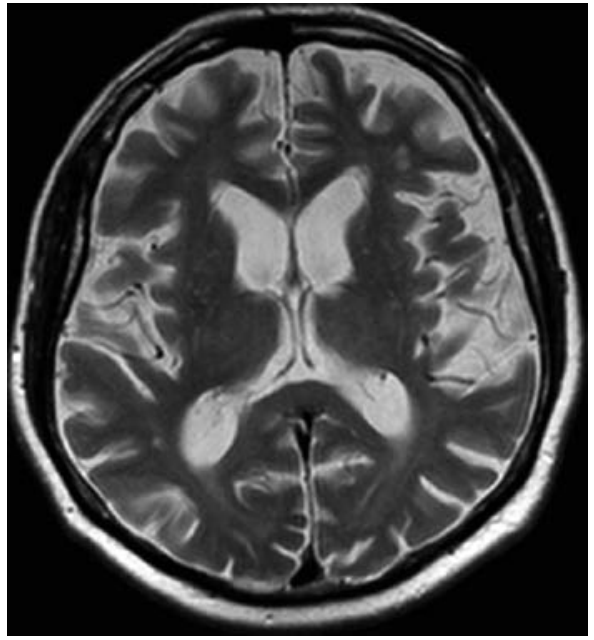

tikou zůstávají hypointenzní ložiska v dorzálním putamen, patrná zvláště na T2 a T2* vážených obrazech, ale i na T1 vážení.
V oblasti substantia nigra jsou pozorovány stejné změny jako u PD, tedy zúžení či vymizení relativně hyperintenzního proužku, odpovídajíc pars compacta substantitae nigrae na T2 vážených obrazech spinového echa a celková degenerace tohoto jádra spojená s rozšiřenou zónou hypointenzního signálu s často neostrými hranicemi na stejné sekvenci (Vymazal, 2009).

$\checkmark$ diferenciální diagnostice mezi PN a různými formami MSA může napomoci i protonová MR spektroskopie, kdy poměr NAA/Cr (N-acetylaspartát ku kreatinu) a NAA/Cho (N-acetylaspartát ku cholinu) bývá u Parkinsonovy nemoci normální, kdežto u MSA obecně je snižen (obrázek 4). V oblasti kmene bývá také pozorován (obdobně jako u MSA - C) tzv. hot-cross-bun príznak (glióza kmene) (obrázek 5).

$\checkmark$ současné době bylo prokázáno, že změny v průměrné difuzivitě (mean diffusivity, MD) jsou poměrně spolehlivým parametrem, který Ize prokázat i MSA typ P i C v středním mozečkovém pedunculu a v putamen (Rulseh et al., 2016).

\section{MSA - C}

Onemocnění se projevuje progredujícím mozečkovým syndromem, který zpočátku může být izolovaný, postupně se mohou prídávat autonomní poruchy (ortostatická hypotenze, sfinkterové poruchy) a parkinsonský syndrom.

\section{MR charakteristika}

Kromě výše popsaných MR charakteristik typických pro MSA - P je vyjádřena atrofie mozečku a mozkového kmene, disproporční k atrofii supratentoriální (Postuma, 2016; Vymazal, 2009) (obrázek 6).

\section{Progresivní supranuklární paréza (PSP)}

PSP označovaná jako morbus SteeleRichardson-Olszewski byla popsána těmito autory v roce 1964. Parkinsonský syndrom, který postihuje hlavně axiální svalstvo, bývá časným príznakem onemocnění. Specifickým príznakem je paréza pohybu dolů. Další důležitá klinická symptomatologie zahrnuje posturální instabilitu, kognitivní poruchy až demenci (Vymazal, 2009).

\section{MR charakteristika}

Kromě změn v oblasti substantia nigra a striata, popsaných u MSA Ize pomocí MR velmi dobře detekovat atrofii mezencefala, zvláště tecta, a to
Obr. 8. Progresivní supranukleární paréza; MPRAGE sekvence v T1 vážení; sagitální rovina je vhodná k průkazu oploštění tecta mezencefala, které je typické pro tuto diagnózu; patrny pohybové artefakty

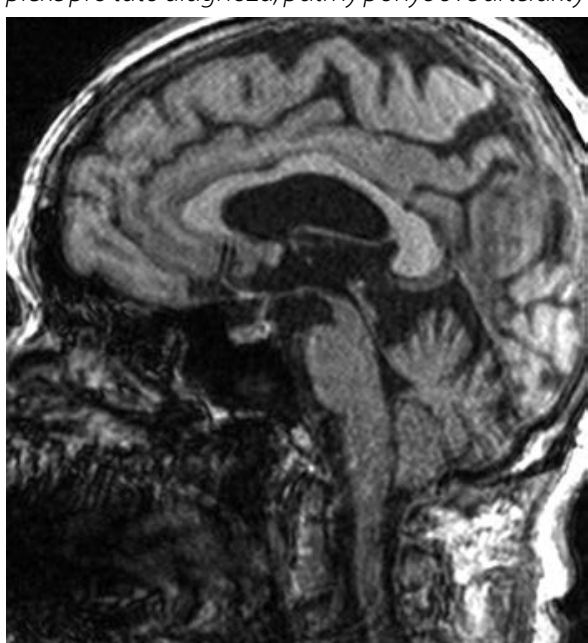

na tenkých sagitálních řezech, obvykle v T1 vážení (obrázek 7), tzv. příznak kolibříka (hummingbird sign) (Postuma, 2016). Specificita tohoto příznaku narůstá zvláště při konvexním tvaru tecta. Krom tohoto příznaku bývá přítomen i příznak svlačce (morning glory sign), reflektující tvara mezencefala v transverzální rovině (Grambalová et al., 2010).

\section{Vaskulární parkinsonizmus}

Otázka vaskulárního parkinsonského syndromu zưstává stále poněkud sporná.

Diagnóza vaskulárního PS přichází nejspíše v úvahu u pacientů s výrazným MR nálezem (viz níže) a s horší nebo žádnou odpovídavostí na dopaminergní léčbu.

MR a do jisté míry i CT významně přispěje k diferenciální diagnostice mezi Parkinsonovou nemocí, kde standardní MR obraz bývá prakticky v normě a vaskulárním parkinsonizmem, kde na T2-vážených sekvencích a sekvencích FLAIR nacházíme vícečetné ischemie zvláště v bílé, ale i v šedé hmotě (Postuma, 2016) (obrázek 8).

\section{Huntingtonova nemoc}

Prvý popis nemoci pochází od George Huntingtona z roku 1872. Ve světle současného poznání je HN autosomálně dominantnědědičné neurodegenerativní onemocnění, kódované mutací IT 15 genu na krátkém raménku chromozómu 4. Defektní gen způsobuje expanzi polyglutaminového traktu $v$ amino-terminální části proteinu nazvaného huntingtin. $V$ roce 1993 byl objasněn charakter mutace - expanze trinukleotidu (tripletu) CAG na krátkém raménku 4. chromozomu (4p 16.3) (8). 
Obr. 9. Vaskulárníparkinsonizmus; vícečetné ažsplývajici ischemickézměnyv biléhmotěna FLAIR sekvenci

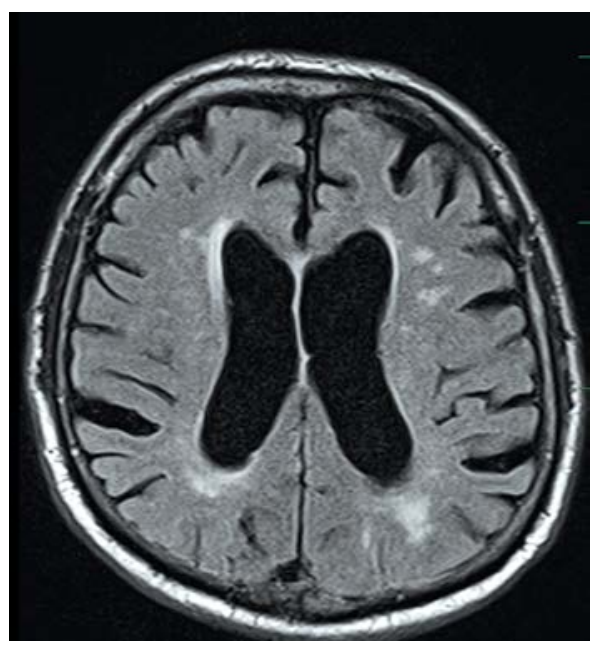

Obr. 10. Wilsonova choroba - TSE sekvence v T2 vážení Hyperintenzní signál z obou putamin

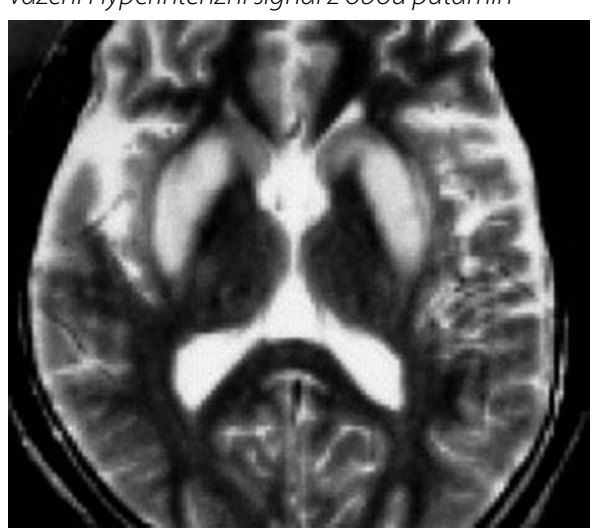

Obr. 11. PKAN 16letá pacientka - TSE sekvence v T2 vážení s výraznou a věku neadekvátní hypointenzitou v obou globi pallidi; centrální ložiska hyperintenzního signálu v globi pallidi predstavují príznak očítygra

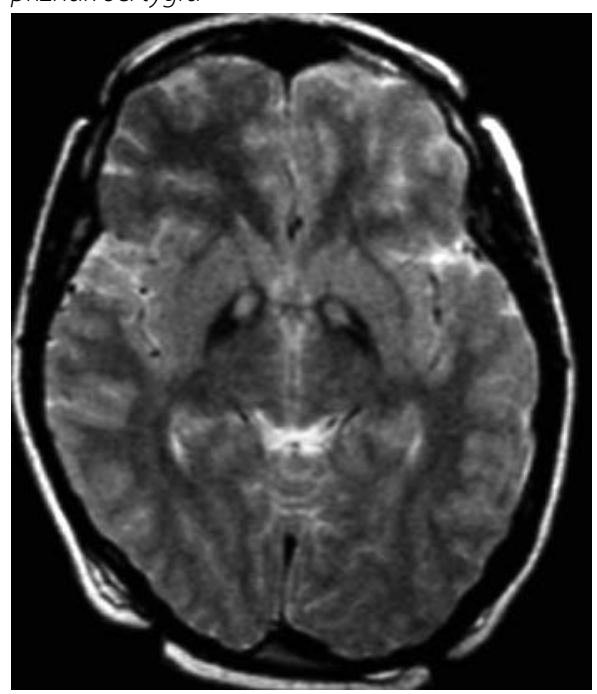

Zdraví jedinci mohou mít multiplikace CAG tripletu do 35 repeticí. Počet tripletů 36-39 představuje určitou šedou zónu neúplné penetrace onemocnění. Zde již však výrazně hrozí další možná expanze tripletů u potomstva a tím způsobené onemocnění. Od 40 tripletů výše nastá-
Obr. 12. Jacob Creutzfeldova nemoc - zvýšení intenzity signálu v oblasti bazálních ganglií

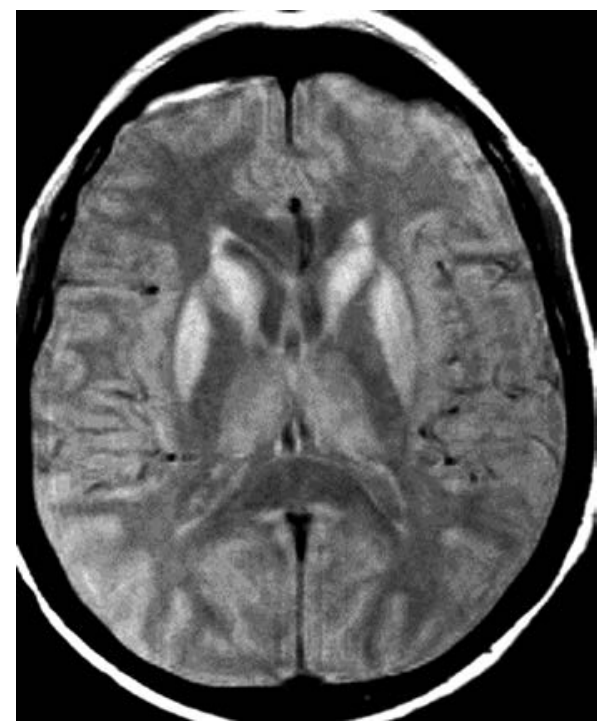

vá úplná penetrance. Nositel takového počtu tripletů onemocní, pokud se dožije klinických projevů HN (Snell et al., 1993). Čím je počet CAG tripletů vyšší, tím pacient dřive onemocní.

Onemocnění, pokud vznikne v dospělosti, se zpravidla projevuje progredující generalizovanou choreou v kombinaci s psychiatrickými príznaky. Postupem času se objevuje i dystonie, poruchy kognice a další. Pacient nakonec končí upoután na lůžko a umírá většinou na interkurentní infekty.

\section{MR charakteristika}

Základní MR (i CT) obraz je charakterizován nápadnou dilatací frontálních rohů postranních komor, která je korelátem atrofie striata, především v oblasti caput nuclei caudati. MR obraz pak ukáže bud' izolovanou nebo výrazně akcentovanou dilataci frontálních rohů se ztrátou jejich obvyklého zakřivení, s menším postižením ostatních částí mozku. Bývá prítomna celková ne príliš výrazná atrofie (obrázek 9) (Vymazal, 2009; Vymazal et al., 2007).

\section{Wilsonova nemoc}

Klinicky varietní obraz této nemoci vyžaduje, aby diagnostika zahrnující biochemické vyšetření, MR vyšetření event. genetické vyšetření, byla provedena vždy, pokud se extrapyramidová symptomatologie objeví u jedince mladšího 55 let. Onemocnění predilekčně postihuje centrální nervovou soustavu a játra.

\section{MR charakteristika}

Nejčastějším MR příznakem Wilsonovy choroby je zvýšená intenzita signálu na T2 vážených
Obr. 13. a) normotenzní hydrocefalus s typicky ostrým úhlem voblasti corpus callosum na koronárním T2 váženém rezu vúrovni commisura posterior; b) subkortikální atrofie s dilatací komorového systému ve stejném úrovni s tupým úhlem v oblasti corpus callosum

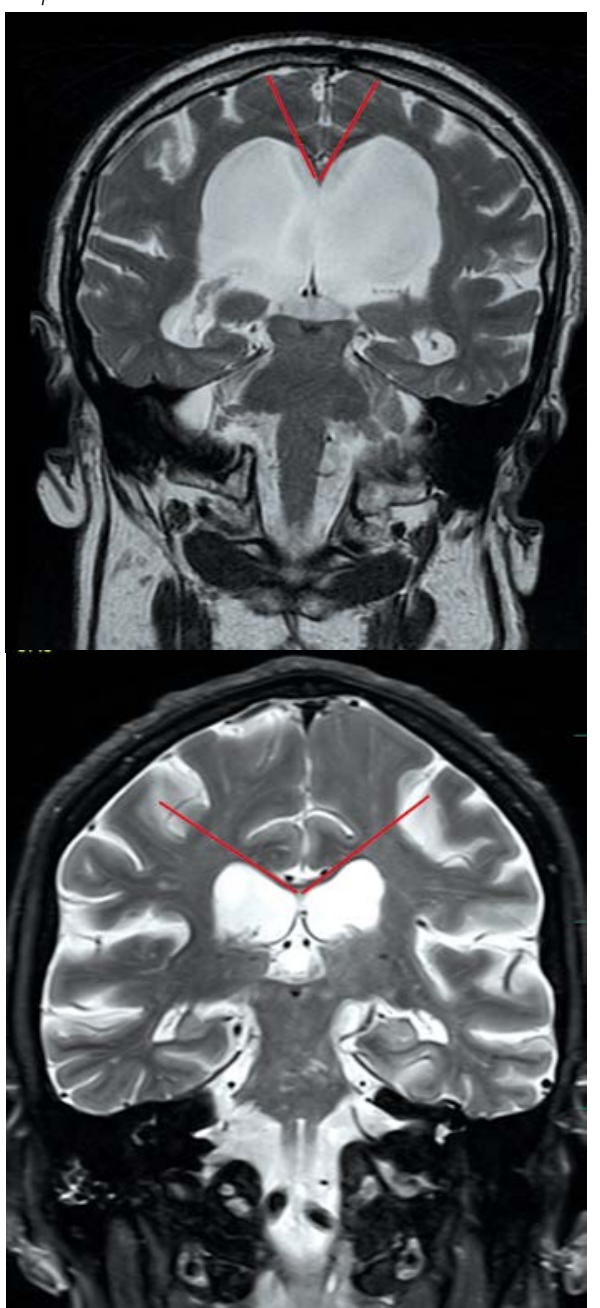

obrazech a sekvenci FLAIR v oblasti bazálních ganglií, zvláště putamen, prrípadně v thalamu (obrázek 10). Zvýšená intenzita signálu se může propagovat až do meuzencefala a vytvářen tzv. prríznak pandy (Singh et al., 2011). Léze při onemocnění jsou i v n. dentatus, ruber, častá je „pruhovitá" změna signálu hypo- a hypersignální v bazálních gangliích.

Samotný magnetický moment mědi je poměrně nízký, proto na MR zobrazujeme reaktivní gliózu, nikoliv pak vlastní akumulaci mědi.

\section{PKAN}

Vzhledem k velmi typickému MR obrazu uvádíme i vzácné autosomálně recesivně vázané onemocnění PKAN (patnothenate-kinase associated neurodegneration), charakterizované převážně v dětství se rozvíjející a rychle progredující axiální dystonií. V MR obraze, který je prakticky patognomický, dominují 
hypointenzní ložiska převážně v globus pallidus a substantia nigra na T2 a predevším T2* vážených obrazech. V centru hypointenzního ložiska v pallidu bývá hyperintenzní útvar, většinou symetrický v obou pallidech, nazývaný „příznak očí tygra” (obrázek 11). Naštěstí s tímto fatálním onemocněním se neurolog v klinické praxi setká jen zř́ldka.

\section{Jacob-Creutzfeldtova nemoc}

Extrapyramidová symptomatologie mưže doprovázet i vzácnou Jacob-Creutzfeldtovu nemoc (CJD) a její variety, které řadíme mezi tzv. prionové spongiformní encefalopatie. Vždy se jedná o velmi

\section{LITERATURA}

1. Anderson M. Normal pressure hydrocephalus. Br Med J (Clin Res Ed) 1986; 293: 837-838.

2. Duguid JR, De La Paz R, DeGroot J. Magnetic resonance imaging of the midbrain in Parkinson's disease. Ann Neurol 1986; 20: 744-747.

3. Grambalová Z, Hluštík P. Heřman M, Kaňovský P. Přítomnost tzv. typických MR nálezů u multisysté - mové atrofie a progresivní supranukleární paralýzy - retrospektivní pilotní studie. Ces Slov Neurol Neurochir 2010; 73: 538-541.

4. Hadley DM, Grant R, Condon B. Normal pressure hydrocephalus. Br Med J (Clin Res Ed) 1986; 293: 1173-1117.

5. MacDonald E, Ambrose CHM, Duyao MP, Myers RH, Lin C, Srinidhi L, Barnes G, Taylor SA, James M, Groot N, MacFarlane $\mathrm{H}$, Jenkins B, Anderson MA, Wexler NS, Gusella JF, Bates GP, Baxendale S, Hummerich H, Harper PS. A novel gene containing a trinucleotide repeat that is expanded and unstable on Huntington's disease chromosomes. The Huntington's Disease Collaborative Research Group. Cell rychle progredující neurologickou symptomatologii - napr. myoklonus, dystonii, alien limb syndrom $\checkmark$ kombinaci s postižením kognice.

MR obraz je i v relativně časných stadiích choroby poměrně typický a může pomoci urychlit diagnostiku tohoto fatálního onemocnění. Jsou patrné okrsky zvýšené intenzity signálu na T2 vážených obrazech, více na obrazem FLAIR v bazálních gangliích (zvláště striatu) a v cerebrálním kortexu (častěji okcipitálně) (Ukisu et al., 2006) (obrázek 12). V poslední době se zdají být s výhodou difuzně vážené obrazy (DWI), které prokazují i diskrétní kortikální léze dřive, než standardní MR vyšetření.

\section{3; 72: 971-983.}

6. Postuma RB. Resting state MRI: a new marker of prodromal neurodegeneration? Brain 2016; 139: 2106-2108.

7. Rulseh AM, Keller J, Rusz J, Syka M, Brozova H, Rusina R, Havrankova P, Zarubova K, Malikova H, Jech R, Vymazal J. Diffusion tensor imaging in the characterization of multiple system atrophy Neuropsychiatr Dis Treat. 2016; 12: 2181-2187.

8. Růžička E, Urgošík D, Jech R, Serranová T, Volfová M, Roth J, Vymazal J, Mečír P, Nováková L, Nováková O, Ulmanová O, Brožová H, Dušek P, Špačková N, Liščák R, Vladyka V. Hluboká mozková stimulace $v$ léčbě Parkinsonovy nemoci a 18. třesu: Pražská zkušenost 1998-2003: Česká a slovenská neurologie a neurochirurgie 2004; 19(67/100)6: 423-436.

9. Singh P, Ahluwaria A, Sagar K. Greval SC. Wilson's disease: MRI features J Pediatr Neurosci. 2011; 6(1): 27-28.

10. Snell RG, MacMillan JC, Cheadle JP, Fenton I, Lazarou LP, Davies P, MacDonald ME, Gusella JF, Harper PS, Shaw
V rámci širší diferenciální diagnostiky extrapyramidových nemocí je třeba zmínit i chronický subdurální hematom, prípadně normotenzní hydrocefalus, které se klinicky rovněž mohou celkovým zpomalením nebo poruchou chůze, která může imitovat parkinsonský syndrom. Rozeznat normtenzní hydrocefalus od prosté atrofie pomáhá např. úhel corpus callosum na koronárních řezech, který je u NPH na rozdíl od atrofie ostrý (obrázek 13) (Anderson, 1986; Hadley, Grant et Condon, 1986). Jedná se o cenný príznak, nicméně nemusí být vždy vyjádřen. Na obě onemocnění je nutné pomýšlet při nejasné poruše chůze, nebot’ jsou obě specificky řešitelné.

DJ. Relationship between trinucleotide repeat expansion and phenotypic variation in Huntington's disease. Nat Genet 1993; 4: 393-397.

11. Ukisu R, Kushihashi T, Tanaka E, Baba M, Usui N, Fujisawa $H$, Takenaka H. Diffusion-weighted MR imaging of early-stage Creutzfeldt-Jakob disease: typical and atypical manifestations. Radiographics 2006; 26(Suppl. 1): S191-204.

12. Vymazal J. Magnetická rezonance nervové soustavy: Radioloigcké a klinické aspekty. II Neurodegenerativní onemocnění. M-DIAG Publishing 2009

13. Vymazal J, Klempir J, Jech R, Židovská J, Syka M, Růžička E, Roth J. MR relaxometry in Huntington's disease: correlation between imaging, genetic and clinical parameters. J Neurol Sci 2007; 263: 20-25.

14. Vymazal J, Urgosik D, Bulte JW. Differentiation between hemosiderin - and ferritin-bound brain iron using nuclear magnetic resonance and magnetic resonance imaging. Cell Mol Biol (Noisy-le-grand) 2000; 46: 835-842. 